\title{
Hubungan Pre Eklamsia Berat Pada Ibu Bersalin Dengan Asfiksia Neonatorum Di RSUD Dr. H. Moch Ansari Saleh Banjarmasin
}

\author{
Ika Mardiatul Ulfa 1, Dewi Pusparani Sinambela2 \\ Akademi Kebidanan Sari Mulia Banjarmasin \\ jl. Pramuka No. 02 Banjarmasin, Kalimantan Selatan, Indonesia \\ korespondensi Email: icka_ulfa86@yahoo.com
}

DOI: https://doi.org/10.33859/dksm.v10i1.432

\begin{abstract}
Abstrak
Latar belakang: pre eklampsia masih menjadi salah satu penyebab kematian ibu dan bayi, begitu juga dengan angka kematian bayi yang disebabkan oleh asfiksia neonatorum yang dikarenakan pre eklapsia pada masa kehamilan. Salah satu penyebab tingginya kematian bayi di Indonesia adalah asfiksia neonatorum yaitu sebesar 33,6\%.

Tujuan: Mengetahui hubungan antara pre eklamsia berat (PEB) dengan kejadian asfiksia neonatorum di RSUD Dr. H. Ansari Saleh Banjarmasin

Metode: Penelitian ini merupakan penelitian kuantitatif dengan jenis penelitian analitik yang mengunakan pendekatan crossectional. Populasi adalah Bayi dengan Asfiksia Neonatorum sebanyak 941 bayi, dengan teknik pengambilan Systematic Random Sampling didapat sampel sebanyak 100 bayi. Teknik analisa data dengan Chi-Square.

Hasil: Bayi yang mengalami asfiksia pada ibu bersalin dengan pre eklampsia berat adalah sebanyak 55 responden $(55 \%)$ dan yang tidak mengalami pre eklampsia adalah 45 bayi $(45 \%)$ dan ada hubungan pre eklamsia berat (PEB) dengan kejadian asfiksia neonatorum dengan preeklamsia berat beresiko 1,6 kali lebih beresiko mengalami asfiksia neonatorum dibandingkan dengan tidak mengalami preeklamsia berat.

Simpulan: Ada hubungan antara pre eklamsia berat (PEB) dengan kejadian asfiksia neonatorum di RSUD Dr. H. Ansari Saleh Banjarmasin
\end{abstract}

Kata Kunci : asfiksia neonatorum, bayi baru lahir, ibu bersalin, pre eklamsia berat 
Dinamika Kesehatan Jurnal Kebidanan dan Keperawatan Vol 10 No. 1 Juli 2019 (ISSN: 2086-3454 EISSN: 2549-4058)

url: http://ojs.dinamikakesehatan.unism.ac.id DOI : https://doi.org/10.33859/dksm.v10i1

Hubungan Pre Eklamsia Berat Pada Ibu Bersalin Dengan Asfiksia Neonatorum

Di RSUD Dr. H. Moch Ansari Saleh Banjarmasin

\title{
Relationship Between Severe Pre Eklamsia On Maternity With Asfiksia Neonatorum
}

In Dr. H. Moch Ansari Saleh Hospital Banjarmasin

\begin{abstract}
Background: pre-eclampsia is still one of the causes of maternal and infant mortality, as well as infant mortality caused by neonatal asphyxia due to preeclampsia during pregnancy. One of the causes of high infant mortality in Indonesia is neonatal asphyxia, which is $33.6 \%$.

Objective: To find out the relationship between severe pre-eclampsia (PEB) and the incidence of neonatal asphyxia in Dr. RSUD H. Ansari Saleh Banjarmasin

Method: This study is a quantitative study with a type of analytic research that uses a crossectional approach. Population is as many as 941 infants with neonatal asphyxia, with a systematic random sampling technique obtained as many as 100 infants. Data analysis techniques with Chi-Square.

Results: Infants who experienced asphyxia in mothers with severe pre-eclampsia were 55 respondents $(55 \%)$ and those who did not have pre-eclampsia were 45 infants (45\%) and there was a relationship between severe pre-eclampsia (PEB) and neonatal asphyxia with severe preeclampsia. a risk of 1.6 times more risk of developing neonatal asphyxia compared to not having severe preeclampsia.

Conclusion: There is a relationship between severe pre-eclampsia (PEB) and the incidence of neonatal asphyxia in Dr. H. Ansari Saleh Banjarmasin
\end{abstract}

Keywords: neonatal asphyxia, newborns, maternity, severe preeclampsia

\section{PENDAHULUAN}

Penyebab utama kematian ibu menurut

World Health Organization (WHO) dalam

bidang obstetri yaitu Pendarahan (45\%),

Infeksi (15\%), dan Hipertensi dalam

kehamilan (Preeklamsia) $\quad 13 \%$

(Roeshadi,2006). Preeklamsia adalah suatu

kelainan pada kehamilan yang termasuk

penyakit Hipertensi yang berdampak pada

kehamilan dan kematian bayi. Preeklamsi

merupakan salah satu penyebab dari kematian perinatal dan kehamilan dan banyak terjadi diseluruh dunia (WHO,2011).

Kejadian Preeklamsi diperkirakan sebesar 3-10\% dari seluruh kehamilan. Berdasarkan data dari WHO menunjukan bahwa Hipertensi menyebabkan $16 \%$ dari seluruh angka kematian ibu di negara berkembang, 9\% di Afrika dan Asia dan yang paling tinggi di Amerika Latin dan Caribbean yang mencapai angka 26\% (Jeyabalan, 2013).

Angka kematian bayi berdasarkan World Health Organization (WHO), sebesar 
Dinamika Kesehatan Jurnal Kebidanan dan Keperawatan Vol 10 No. 1 Juli 2019 (ISSN: 2086-3454 EISSN: 2549-4058) url: http://ojs.dinamikakesehatan.unism.ac.id DOI : https://doi.org/10.33859/dksm.v10i1

Hubungan Pre Eklamsia Berat Pada Ibu Bersalin Dengan Asfiksia Neonatorum Di RSUD Dr. H. Moch Ansari Saleh Banjarmasin

10.000.000 per tahun (Katiandagho \&

Kusmiayi,2015). Laporan WHO juga

menyebutkan bahwa AKB kawasan Asia

Tenggara merupakan kedua yang paling tinggi

yaitu sebesar 142 per 1.000 kelahiran hidup

setelah Kawasan Afrika. Di tahun 2011, Indonesia merupakan Negara dengan AKB tertinggi kelima untuk Negara ASEAN yaitu 35 per 1.000 kelahiran hidup, dimana Myanmar 48 per 1.000 kelahiran hidup, Laos dan Timur Leste 46 per 1.000 kelahiran hidup, dan Kamboja 36 per 1.000 kelahiranhidup (Syaiful\&Khudzaifah 2016). Laporan World Health statistik 2014 menyebutkan bahwa angka kematian neonatus pada tahun 2012 di dunia adalah 21 per 1.000 kelahiran hidup (WHO,2014).

Untuk mengurangi Angka Kematian Ibu (AKI) dan Angka Kematian Bayi (AKB), maka Pemerintah Indonesia membuktikan komitmen dan keseriusan dalam melaksanakan tujuan Pembangunan Berkelanjutan (TPB) atau Sustainable Development Goals (SDGs). Angka kematian ibu (AKI) merupakan salah satu masalah krusial di dunia. Sampai saat ini
AKI melahirkan belum dapat turun seperti yang diharapkan. Dengan dibuatnya rancangan Sustainable Development Goals (SDGs) atau Tujuan Pembangunan Berkelanjutan 2030 atau disebut juga dengan Global Goals di Jakarta 1 Desember 2015, Kementerian Kesehatan Republik Indonesia mendukung penuh 17 poin tujuan SDGs. Posisi kesehatan dalam kerangka SDGs yang menjadi perhatian khusus di sektor kesehatan salah satunya adalah poin nomor tiga yaitu tentang kejadian Preeklamsia di Indonesia sekitar 7$10 \%$ dari seluruh kehamilan (Birawa et al.,2009). Preeklamsia berat (PEB) adalah penyakit dengan tanda-tanda TRIAS yaitu Hipertensi, proteinuria dan edema yang timbul karena kehamilan, tetapi dapat terjadi sebelumnya, misalnya pada Mola Hidatidosa. (Prawirohardjo 2007). Faktor-faktor penyebab pre eklamsia berat sampai saat ini belum di ketahui, tetapi umumnya di sebebkan oleh Vasospasme Arteriola. Dimana terdapat 13 target didalam poin nomor tiga tersebut yang salah satunya menyebutkan Pada 2030, mengurangi angka kematian ibu hingga 
Dinamika Kesehatan Jurnal Kebidanan dan Keperawatan Vol 10 No. 1 Juli 2019 (ISSN: 2086-3454 EISSN: 2549-4058) url: http://ojs.dinamikakesehatan.unism.ac.id DOI : https://doi.org/10.33859/dksm.v10i1

Hubungan Pre Eklamsia Berat Pada Ibu Bersalin Dengan Asfiksia Neonatorum Di RSUD Dr. H. Moch Ansari Saleh Banjarmasin

dibawah 70 per 100.000 kelahiran hidup

(Wibowo \& Rachimhadhi, 2012).

Selain Angka Kematian Ibu (AKI) SDGs juga mempunyai tujuan untuk menurunkan Angka Kematian Bayi (AKB). Kematian neonatus menjadi 12 per 1.000 di tahun 2030 (kemenkes,2015). Angka Kematian Bayi (AKB) di Indonesia 34 per 1000 kelahiran hidup. Bila dirincikan 157.000 bayi meninggal dunia per tahun atau 430 bayi meninggal dunia perhari (SDKI,2013). Dalam Sustainable Development Goals (SDGs), Indonesia menargetkan pada tahun 2030 kedepan Angka Kematian Bayi (AKB) menurun menjadi 12 bayi per 1000 kelahiran. Komplikasi yang menjadi penyebab kematian terbanyak yaitu Berat Badan Lahir Rendah (BBLR), Asfiksia dan Infeksi (Riskesdas, 2007).

Kejadian asfiksia neonatorum masih menjadi masalah serius di Indonesia. Salah satu penyebab tingginya kematian bayi di Indonesia adalah asfiksia neonatorum yaitu sebesar 33,6\%. Angka kematian karena asfiksia di Rumah Sakit Pusat Rujukan Propinsi di Indonesia sebesar 41,94\%. Di
Indonesia angka kejadian asfiksia kurang lebih

40 per 1000 kelahiran hidup, secara keseluruhan 110.000 neonatus meninggal setiap tahun karena asfiksia. Di daerah pedesaan Indonesia angka kejadian asfiksia neonatorum sebanyak 31-56,5\%. Dan asfiksia menjadi penyebab 19\% dari 5 juta kematian bayi baru lahir setiap tahun (Setyobudi, 2009).

Tujuan indikator Kementerian Kesehatan Kalimantan Selatan bersifat dampak (impact atau outcome). Dalam peningkatan status kesehatan masyarakat, indikator yang akan dicapai salah satunya adalah menurunkan angka kematian ibu dan menurunkan angka kematian bayi dari 32 menjadi 24 per 1.000 kelahiran hidup. Akses masyarakat terhadap pelayanan kesehatan dasar sudah meningkat yang ditandai dengan meningkatnya jumlah puskesmas, dibentuknya Pos Kesehatan Desa (Poskesdes) di tiap desa, dan dijaminnya pelayanan kesehatan dasar bagi masyarakat miskin di Puskesmas dan Rumah sakit melalui Jaminan Kesehatan Masyarakat (Jamkesmas), Jamkesda dan Jamkesprov. Namun akses terhadap pelayanan kesehatan belum merata di 
Dinamika Kesehatan Jurnal Kebidanan dan Keperawatan Vol 10 No. 1 Juli 2019 (ISSN: 2086-3454 EISSN: 2549-4058) url: http://ojs.dinamikakesehatan.unism.ac.id DOI : https://doi.org/10.33859/dksm.v10i1

Hubungan Pre Eklamsia Berat Pada Ibu Bersalin Dengan Asfiksia Neonatorum Di RSUD Dr. H. Moch Ansari Saleh Banjarmasin

seluruh wilayah Kalimantan Selatan, masih terbatasnya sarana pelayanan kesehatan dan tenaga kesehatan di daerah tertinggal dan terpencil.

Berdasarkan Kebijakan Regionalisasi Pelayanan Kesehatan Rumah Sakit di Provinsi Kalimantan Selatan, RSUD Dr. H. Moch. Ansari Saleh Banjarmasin ditetapkan sebagai Rumah Sakit Rujukan. Konsep pengembangan Rumah Sakit DR. H. Moch Ansari Saleh sebagai rumah sakit yang memiliki 2 (dua) unggulan pelayanan spesialistik, yaitu pusat pelayanan penyakit Neuroscience dan pusat pelayanan penyakit Infeksi dan penyakit tropik. Data yang diperoleh dariRumah Sakit Umum Daerah (RSUD) Dr. H. Moch. Ansari Saleh Banjarmasin pada tahun pada tahun 2014 terdapat jumlah persalinan 5.951 diantaranya terdapat PEB $265(44,5 \%)$ dan jumlah bayi lahir 2,861 diantaranya asfiksia $545(19,0 \%)$ dan meninggal karena asfiksia 30 (9,44\%), pada tahun 2015 jumlah persalinan 4.150 sedangkan PEB 292 (55,2\%) dan jumlah bayi lahir 2.879 dan asfiksia $541(18,7 \%)$ dan bayi meninggal karena asfiksia $66(8,78 \%)$ sedangkan tahun 2016 jumlah persalinan 5.285 dan PEB 386 (73,0\%) dan jumlah bayi lahir 4.516 asfiksia $941(20,8 \%)$, dan meninggal karena asfiksia $25(9,16 \%)$.

Berdasarkan data tersebut kejadian PEB dan Asfiksia Neonatorum terjadi peningkatan dari tahun ke tahun. Oleh sebab itu penelitian tentang Hubungan Pre Eklamsia Berat (PEB) dengan Kejadian Asfiksia Neonatorum di RSUD Dr. Moch. H. Ansari Saleh Banjarmasin dilakukan.

\section{METODE}

Metode peneltian ini menggunakan analitik dengan pendekatan crossectional. Populasi adalah bayi dengan asfiksia neonatorum yang lahir atau rujukan di Dr. $\mathrm{H}$. Moch Ansari Saleh Banjarmasin dengan jumlah 941 Bayi. Sampel penelitian ini adalah 100 bayi dengan asfiksia neonatorum, dengan mengunakan teknik Systematic Random Sampling.

\section{HASIL}


Dinamika Kesehatan Jurnal Kebidanan dan Keperawatan Vol 10 No. 1 Juli 2019 (ISSN: 2086-3454 EISSN: 2549-4058)

url: http://ojs.dinamikakesehatan.unism.ac.id DOI : https://doi.org/10.33859/dksm.v10i1

Hubungan Pre Eklamsia Berat Pada Ibu Bersalin Dengan Asfiksia Neonatorum

Di RSUD Dr. H. Moch Ansari Saleh Banjarmasin

1. Karakteristik Responden asfiksia

neonatorum

a. Umur dengan kejadian asfiksia

neonatorum

Tabel 1 Karakteristik responden berdasarkan umur di RSUD dr. H. Moch Ansari Saleh Banjarmasin

\begin{tabular}{lll}
\hline Umur & Jumlah & Persentase \\
\hline$<20$ Tahun & 10 & $10 \%$ \\
\hline $\begin{array}{l}20-35 \\
\text { Tahun }\end{array}$ & 69 & $69 \%$ \\
\hline$>35$ Tahun & 21 & $21 \%$ \\
\hline Jumlah & 100 & $100 \%$ \\
\hline
\end{tabular}

Hasil penelitian menunjukan

bahwa proporsi ibu yang melahirkan

bayi dengan asfiksia neonatorum

terbanyak berada pada kategori umur

20-35 tahun.

b. Umur kehamilan dengan Asfiksia

Neonatorum

Tabel 2 Karakteristik responden berdasarkan umur kehamilan dengan Asfiksia Neonatorum di RSUD dr. H. Moch Ansari Saleh Banjarmasin

Umur frekuensi Persentase

Kehamilan

\begin{tabular}{lll}
\hline $0-12$ minggu & 0 & 0 \\
\hline $13-28$ minggu & 51 & $51 \%$ \\
\hline$>28$ mingg & 49 & $49 \%$ \\
\hline Jumlah & &
\end{tabular}

Hasil penelitian menunjukan bahwa proporsi ibu dengan umur kehamilan 13-28 minggu lebih banyak yang melahirkan bayi dengan asfiksia neonatorum yaitu 51 responden $(51 \% \%)$.

2. Analisa Univariat

a. Kejadian Preeklamsia berat

Tabel 3 Kejadian Preeklamsia berat di RSUD dr. H. Moch Ansari Saleh Banjarmasin

\begin{tabular}{lll}
\hline PEB & Frekuensi & Persentase \\
\hline Iya & 55 & $55 \%$ \\
\hline Tidak & 45 & $45 \%$ \\
\hline Jumlah & 100 & $100 \%$
\end{tabular}

Berdasarkan pada tabel 3 dapat dilihat bahwa proporsi ibu dengan pre eklamsi berat lebih banyak yaitu 55 (55\%) sedangkan proporsi ibu dengan tidak pre eklamsi berat yaitu $45(45 \%)$

b. Asfiksia Neonatorum

Tabel 4 Distribusi frekuensi berdasarkan asfiksia neonatarum di RSUD dr. H. Moch Ansari Saleh Banjarmasin

\begin{tabular}{ccc}
\hline Asfiksia neonatorum & $\mathrm{f}$ & $\%$ \\
\hline Asfiksia & 100 & 100 \\
Tidak Asfiksia & 0 & 0 \\
\hline Jumlah & 100 & 100 \\
\hline
\end{tabular}


Dinamika Kesehatan Jurnal Kebidanan dan Keperawatan Vol 10 No. 1 Juli 2019 (ISSN: 2086-3454 EISSN: 2549-4058)

url: http://ojs.dinamikakesehatan.unism.ac.id DOI : https://doi.org/10.33859/dksm.v10i1

Hubungan Pre Eklamsia Berat Pada Ibu Bersalin Dengan Asfiksia Neonatorum

Di RSUD Dr. H. Moch Ansari Saleh Banjarmasin

Berdasarkan pada tabel 4 dari 100

ibu yang melahirkan di RSUD dr. H.

Moch Ansari Saleh Banjarmasin semua

melahirkan bayi dengan asfiksia

neonatorum.

c. Analisa Bivariat

Tabel5 Tabulasi silang pre eklamsia berat (PEB) dengan kejadian asfiksia neonatorum di RSUD dr. H. Moch Ansari Saleh Banjarmasin

\begin{tabular}{lcccccc}
\hline \multirow{2}{*}{$\begin{array}{c}\text { Asfiksia } \\
\text { neonatorum }\end{array}$} & \multicolumn{3}{c}{ Pre eklamsi berat } & \multirow{2}{*}{ Total } \\
\cline { 2 - 6 } & \multicolumn{2}{c}{ Ya } & \multicolumn{2}{c}{ Tidak } & & \\
\cline { 2 - 6 } & $\mathrm{f}$ & $\%$ & $\mathrm{f}$ & $\%$ & $\mathrm{n}$ & $\%$ \\
\hline Ya & 55 & 55 & 45 & 45 & 100 & 100 \\
\hline Tidak & 0 & 0 & 0 & 0 & 0 & 0 \\
\hline Jumlah & 55 & 55 & 45 & 45 & 100 & 100 \\
\hline \multicolumn{6}{c}{ P Value $=0,033$} \\
& OR $=1,688(1,040-2,738)$ \\
\hline
\end{tabular}

Berdasarkan pada tabel 5 dapat dilihat bahwa proporsi bayi dengan afiksia neonatorum lebih banyak ibu yang mengalami pre eklamsi berat yaitu 55 (55\%). Dari hasil analisa didapat $p$ value 0,033 dengan $\mathrm{OR}=1,688$, sehingga dapat disimpulkan bahwa ada hubungan antara pre eklamsia berat (PEB) dengan kejadian asfiksia neonatorum, preeklamsia berat beresiko 1,6 kali lebih beresiko mengalami asfiksia neonatorum dibandingkan dengan

tidak mengalami preeklamsia berat.

\section{PEMBAHASAN}

1. Preeklamsia Berat

Berdasarkan hasi penelitian didapat proporsi ibu dengan pre eklamsi berat lebih banyak yaitu 55 (55\%) sedangkan proporsi ibu dengan tidak pre eklamsi berat yaitu 45 (45\%). Hal ini menunjukkan bahwa sebagian besar ibu pre eklamsi berat akan melahirkan bayi dengan asfiksia.

Hal ini didukung oleh teori Mochtar (2013), tidak mengalami preeklamsia berat adalah suatu keadaan dimana saat kehamilan ibu tidak mengalami kenaikan tekanan darah 160/110 mm/Hg atau lebih, tidak adanya proteiunuria 5 gr atau lebih per liter dalam 24 jam atau kuatitatif 3+ atau kuantitatif $4+$, tidak adanya oliguria (jumlah urin kurang dari 500cc per jam, tidak adanya gangguan serebral, tidak terdapat gangguan penglihatan, tidak merasakan nyeri epigastrium, tidak adanya tanda sianosis, tidak terdapat edema paru, 
tidak terdapat trombosit openi, tidak mengalami gangguan fungsi hati, serta yang terakhir adalah pertumbuhan janin tidak terhambat.

Dapat disimpulan bahwa selama kehamilan preeklamsi berat dapat dicegah dengan cara melakukan pemeriksaan antenatal yang teratur dan bermutu serta teliti, mengenali tanda-tanda sedini mungkin (preeklampsia ringan), lalu diberikan pengobatan yang cukup agar penyakit tidak menjadi lebih berat, waspada terhadap kemungkinan terjadinya dan memberikan penjelaskan kepada ibu mengenai manfaat istirahat dan tidur, ketenangan, serta pentingnya mengatur diet rendah garam, lemak, karbohidrat, dan tinggi protein, juga menjaga kenaikan berat badan jangan berlebihan.

Hasil penelitian menunjukan bahwa proporsi ibu dengan umur kehamilan 13-28 minggu atau trimester kedua lebih banyak yang mengalami preeklamsia berat yaitu $51(51 \%)$
Hasil penelitian ini didukung oleh teori

Rukiyah (2012) preeklamsia berat berhubungan dengan umur kehamilan, ibu dengan umur kehamilan aterm resiko rendah terjadinya preeklamsi sedangkan faktor yang menyebabkan preeklamsia berat antara lain gizi buruk, kegemukan, dan gangguan aliran darah ke rahim. Faktor risiko terjadinya preeklamsia umumnya terjadi pada kehamilan yang pertama kali, kehamilan usia remaja dan kehamilan pada wanita di atas 40 tahun. Faktor risiko lain adalah riwayat tekanan darah tinggi yang kronis sebelum kehamilan, riwayat mengalami preeklamsia sebelumnya, riwayat preeklamsia pada ibu atau saudara perempuan, kegemukan, mengandung lebih dari satu orang bayi, riwayat kencing manis, kelainan ginjal, lupus, atau rematoid arthritis.

Penelitian ini sesuai dengan penelitian Wahyu Utami Ekasari (2015) dengan judul "Pengaruh umur ibu, paritas, usia kehamilan, dan berat lahir bayi terhadap asfiksia bayi pada ibu pre eklamsia berat". 
Dapat disimpulan bahwa bahwa usia kehamilan mempunyai pengaruh terhadap asfiksia pada ibu dengan pre eklamsia berat. Semakin muda usia kehamilan saat ibu melahirkan maka akan memperbesar risiko terjadinya asfiksia karena bayi premature yang lahir pada usia kehamilan kurang dari 37 minggu kondisi oraganorgan vital terutama paru - paru belum siap dan belum mampu melaksanakan pertukaran gas secara efektif sehingga terjadilah asfiksia pada bayi baru lahir.

\section{Asfiksia Neonatorum}

Berdasarkan hasil penelitian mengenai asfiksia neonatorum didapatkan asfiksia sebanyak 100 responden (100\%). Pengambilan sampel dilakukan dengan system random sampling dengan sampel keseluruhan adalah bayi dengan asfiksia.

Dapat disimpulan bahwa semua bayi baru lahir dalam keadaan apapun mempunyai kesulitan untuk beradaptasi pada suhu lingkungan yang dingin. Neonatus yang mengalami asfiksia khususnya, mempunyai sistem pengaturan suhu yang lebih tidak stabil. Hipotermia yang terjadi ini dapat memperlambat pemulihan keadaan asidosis yang terjadi. Namun perlu diperhatikan pula agar tidak terjadi pemanasan yang berlebihan pada tubuh bayi.

Berdasarkan hasil penelitian didapat proporsi ibu dengan umur ibu 20-35 tahun tahun lebih banyak melahirkan bayi asfiksia yaitu 69 (69\%), sedangkan proporsi ibu dengan umur $<20$ tahun lebih sedikit melahirkan bayi dengan asfiksia yaitu $10(10 \%)$.

Menurut teori Wiknkosastro (2011) bahwa umur yang baik untuk terjadinya kehamilan dan persalinan karena organ reproduksi telah siap untuk menerima terjadinya kehamilan dan persalinan, selain kematangan psikis dan emosional untuk menghadapi kehamilan. Umur 20-35 tahun merupakan umur reproduksi sehat. Hal ini sangat baik untuk terjadinya kehamilan. Salah satu faktor yang mempengaruhi tingginya $\mathrm{AKI}$ adalah faktor umur, dimana resiko kematian pada kelompok umur 
Dinamika Kesehatan Jurnal Kebidanan dan Keperawatan Vol 10 No. 1 Juli 2019 (ISSN: 2086-3454 EISSN: 2549-4058)

url: http://ojs.dinamikakesehatan.unism.ac.id DOI : https://doi.org/10.33859/dksm.v10i1

Hubungan Pre Eklamsia Berat Pada Ibu Bersalin Dengan Asfiksia Neonatorum

Di RSUD Dr. H. Moch Ansari Saleh Banjarmasin

kurang dari 20 tahun dan lebih dari 35

tahun. Umur merupakan salah satu faktor

resiko yang berhubungan dengan kualitas

kehamilan atau berkaitan erat dengan

kesiapan fisik ibu dalam reproduksi, tetapi

tidak dengan hasil penelitian yang dilakukan bahawa umur ibu pada kategori 20-35 tahun lebih banyak melahirkan bayi dengan asfiksia neonatorum, sehingga kemungkinan terdapat faktor lain yang dapat menyebabkan persalinan dengan bayi asfiksia neonatorum misalnya riwayat kehamilan dengan pre eklampsia ataupun pada proses persalinan yang terdapat kesulitan atau kelainan.

3. Hubungan pre eklamsia berat (PEB) dengan kejadian asfiksia neonatorum

Hasil penelitian menunjukkan bahwa bayi afiksia neonatorum lebih banyak terjadi pada ibu yang mengalami pre eklampsia berat (PEB) dibandingkan yang tidak mengalami pre eklapsia berat.

Dari hasil analisa didapat $p$ value 0,033 dengan $\mathrm{OR}=1,688$, sehingga dapat disimpulkan bahwa ada hubungan antara pre eklamsia berat (PEB) dengan kejadian asfiksia neonatorum, preeklamsia berat beresiko 1,6 kali lebih beresiko mengalami asfiksia neonatorum dibandingkan dengan tidak mengalami preeklamsia berat.

Hasil penelitian didukung toeri Manuaba (2010) bahwa salah satu faktor yang mengakibatkan terjadinya asfiksia neonatorum diantaranya preeklamsia dan eklamsia berat pada ibu selama kehamilan. Hal ini juga didukung oleh Teori Prawiroharjo (2014) bahwa ibu yang mengalami preeklamsi sebagian melahirkan bayi dengan asfiksia karena aliran darah ke plasenta mengakibatkan gangguan fungsi plasenta, kondisi ini memicu vasokontriksi pembuluh darah ke plasenta menjadi berkurang, hal ini mengakibatkan terjadinya hipoksia pada janin. Akibat lanjut dari hipoksia pada janin adalah gangguan pertukaran gas antara oksigen dan karbodioksida sehingga terjadi asfiksia neonatorum. 
Dinamika Kesehatan Jurnal Kebidanan dan Keperawatan Vol 10 No. 1 Juli 2019 (ISSN: 2086-3454 EISSN: 2549-4058)

url: http://ojs.dinamikakesehatan.unism.ac.id DOI : https://doi.org/10.33859/dksm.v10i1

Hubungan Pre Eklamsia Berat Pada Ibu Bersalin Dengan Asfiksia Neonatorum

Di RSUD Dr. H. Moch Ansari Saleh Banjarmasin

Penelitian ini didukung oleh

peneltian Suci Rahmawati (2013) dengan

judul "Hubungan preeklamsia dengan

kejadian asfiksia neonatorum di RSUD

Pandemah Seropati Bantul Yogyakarta

bahwa ada hubungan yang bermakna

antara preeklampsia dengan kejadian

asfiksia neonatorum.

Dapat disimpulkan bahwa ibu yang mengalami preeklamsi cenderung akan melahiran bayi yang asfiksia, akibat penurunan aliran darah ke plasenta mengakibatkan gangguan plasenta. Hal ini memicu terjadinya hipoksia, hipovolemia, vasospasme, penurunan fungsi utero plasenta dan kerusakan sel endotel pembuluh darah. Pengembangan paru bayi lahir terjadi pada menit-menit pertama kemudian disusul dengan pernafasan ini dimulai dari tekanan mekanik dada ada persalinan disusul dengan keadaan penurunan tekanan oksigen arterial dan peningkatan tekanan karbodioksida arterial sehingga sinusi karotikus menjadi terangksa sehingga terjadi proses bernafas, bila mengalami hiposia akibat suplay oksigen ke plasenta menurun karena efek hipertensi intra uteri maka persalinan maupun pasca persalinan beresiko terjadinya asfiksia pada bayi baru lahir sehingga morbiditas dan mortalitas pada bayi meningkat.

\section{DAFTAR PUSTAKA}

Angsar MD. 2008. Hipertensi dalam kehamilan. Dalam: Saifuddin AB, Rachimhadhi T, Wiknjosastro GH, editor (penyunting). Ilmu Kebidanan. Jakarta: PT Bina Pustaka Sarwono Prawirohardjo.

Ayu Dwi Mufidah. 2015. Perbedaan Kualitas Antenatal Care Pada Ibu Dengan Preeklamsia Berat Terhadap Kejadian Asfiksia Neonatorum Di Rsd. Dr. Soebandi Kabupaten Jember Surabaya (Skripsi).

Cunningham F. G. 2012. Obstetri Williams.Cetakan 23,Jakarta.EGCpp.774797.

Depkes RI. 2009, Buku Kesehatan Ibu dan Anak, Jakarta:

Langelo W, Arsin AA, Russeng S. Faktor risiko kejadian preeklampsia Di RSKD Ibu dan Anak Siti Fatimah Makassar Tahun 20112012. Makassar: Universitas Hasanuddin; 2012. (Skripsi).

Manuaba.2010. Penuntun Kepanitraan Klinik Obstetrik dan Ginekologi.Jakarta: EGC.

Marmi, dkk. 2011. Asuhan Kebidanan Patologi. Yogyakarta: Pustaka Pelajar.

Mochtar, Rustam. 2013. Sinopsis Obstetri Fisiologi, Obsetri Patologi/Editor, Delfi Lutan, Ed. 2-Jakarta: EGC, 
Notoatmodjo, S. 2012. Metodologi penelitian kesehatan. Jakarta: Rineka Cipta.

Prawirohardjo, S., 2014. Ilmu Kebidanan. Edisi Keempat ed. Jakarta: P.T. Bina Pustaka Sarwono Prawirohardjo.

Profil kesehatan profinsi kalimantan selatan. 2016. Dinas kesehatan kalimantan selatan. [Accessed 05 Agustus 2017].

Profil kesehatan RSUD Dr. H. Ansari Saleh Banjarmasin. 2013. RSUD Dr. H. Ansari Saleh. [Accessed 05 Agustus 2017].

Rosi. 2016. Hubungan antara umur ibu dan umur kehamilan ibu dengan kejadian asfiksia neonatorum di Rumah Sakit dr. R. Goeteng Taroenadibrata Purbalingga. Karya Tulis Ilmiah. Viva Medika. 9 (1).

Roziokhan. 2007. Faktor-faktor terjadinya pre eklamsia berat di RS DR. H SOEWONDO Kendal (jurnal).

Sastrawinata, dkk. 2014. Obstetri Patologi Ilmu Kesehatan Reproduksi. Jakarta: EGC.

Sofian. 2011. Sinopsis Obstetri. Jakarta: EGC.

Suci Rahmawati. 2014. Hubungan Preeklamsia Dengan Kejadian Asfiksia Neonatorum di RSUD Panembahan Senopati Bantul Yogyakarta tahun 2013. Skripsi. Sekolah Tinggi Kesehatan Aisyiah Yogyakarta.

Syaiful, Y \& Khudzaifah, U. 2016. Faktor yang berhubungan dengan kejadian asfiksia neonatorum di RS Muhammadiyah Gresik. Journals of Ners Community, 55-60.

WHO, 2011. WHO recommendations for Prevention and treatment of preeclampsia and eclampsia. [Online] Available at:http://apps.who.int/iris/b itstream/10665/44703/1/979241548335_en g.pdf[Accessed 05 Agustus 2017].

Wibowo, B. \& Rachimhadhi, T., 2006. Preeklampsi dan Eklampsi. Jakarta: Yayasan Bina Pustaka Sarwono Prawirohardjo.
Winkjosastro, dkk. 2012. Ilmu Kebidanan. Jakarta: Yayasan Bina Pustaka Sarwono Prawirohardjo.

Yuliandari Prasetya Ningrum. 2015. Hubungan Tekanan Darah Pada Ibu Dengan Asfiksia Neonatorum Di Rsud Dr. Wahidin Sudiro Husodo Mojokerto (skripsi).Poltekes Majapahit. Mojokerto: Poltekes Majapahit Mojokerto. 